\title{
Mechanical Interlock between Steel Ribs and Concrete Exposed to Niger Delta Coastal Marine Region of Nigeria
}

\author{
Sule Samuel ${ }^{1}$, Charles Kennedy ${ }^{2}$, Nwaobakata Chukwuemeka ${ }^{3}$
}

${ }^{1,3}$ Department of Civil Engineering, University of Port Harcourt,

Port Harcourt, Nigeria'

${ }^{2}$ Faculty of Engineering, Department of Civil Engineering, Rivers State University,

Nkpolu, Port Harcourt, Nigeria

Authors E-mail: ${ }^{1}$ samvictory@yahoo.com, ${ }^{2}$ ken_charl@yahoo.co.uk, ${ }^{3}$ makus20002000@gmail.com

\begin{abstract}
Corrosion affects the bond strength between steel and concrete which has led to shortened reinforced concrete structures durability and serviceability. This experimental work evaluated the effect of bond strength of reinforcing steel embedded in concrete of uncoated and coated specimens with the application of invingia gabonensis exudate / resin of thicknesses of $150 \mu \mathrm{m}, 300 \mu \mathrm{m}, 450 \mu \mathrm{m}$, embedded in concrete cubes and partially pooled in corrosive media for 150days accelerated period. Results showed that uncoated specimens corroded before the 150days period. Results of averaged failure bond load of corroded $-43.6558 \%$ against $77.48071 \%$ and $77.10843 \%$ percentile difference of control and coated exudates/resin member. Averaged bond strength load of corroded specimen is $-44.8314 \%$ against $81.26253 \%$ and $116.4128 \%$ percentile difference of control and coated specimens. Averaged maximum slip values is $-29.5904 \%$ against $42.02601 \%$ and $92.81314 \%$ percentile difference of control and coated specimens. Relatively, corroded specimens showed lower failure load and bond strength properties to exudates coated and controlled specimens. Exudates/resins coated specimens exhibited inhibitive characteristics to corrosion with recorded higher low failure load, high bond and maximum slip strength over corroded specimens.
\end{abstract}

Key Words: Corrosion, Corrosion inhibitors, Pull-out Bond Strength, Concrete and Steel Reinforcement

\subsection{INTRODUCTION}

The major durability problem associated with reinforced concrete structures built in the marine environment is corrosion effect. Corrosion affects the bond strength between steel and concrete which has led to reinforced concrete structures durability and serviceability. Tensile stresses due to corrosion in steel reinforcement are generated in the surroundings of the concrete structures which led to early cracks. In addition, steel reinforcement cross sectional - area reduction is noticed thereby causing decreased in ductility of the structure, especially during the occurrence of corrosion pitting An increase in the size of reinforcing steel bars such as expansion and volume is the result of rust products, it results to weakness of the reinforcing steel bar cross- sectional area as well reduces the rate of bonding between reinforcing steel bar and concrete thereby creating stress within the concrete surroundings, ${ }^{[1]}$ found from studies of the effect of steel reinforcement corrosion and bond strength up to approximately $1 \%$ of corrosion level due to the increased roughness of the reinforcing bar surface at early stages with a firmly adherent layer of rust. This is in agreement with experimental results obtained from RC beam tests, which increased in bond strength when the 
degree of corrosion increased up to $4 \%$ due to the increase of radial pressure caused by the expansion of the corrosion products ${ }^{[2]}$.

${ }^{[3]}$ Also demonstrated that in the pre-cracking stage the bond strength is increased, but with an increase in the corrosion level the slip at the ultimate bond strength reduces. Experimental studies showed an increase in bond strength during the initial corrosion level to about $2 \%$. In agreement with the above results, significant literature has been published in this area by $\left({ }^{[4]}\right.$, [5], [6], [7] and ${ }^{[8]}$ ).

[9] Studied and evaluated the effect of corrosion on bond existing between steel and concrete interface of corroded and resins / exudates coated reinforcement with ficus glumosa extracts from trees. Results obtained indicated corrosion potential presence on uncoated concrete cube members. Experimental samples were subjected to tensile and pullout bond strength and obtained results indicated failure load, bond strength and maximum slip values of coated were higher by $33.50 \%, 62.40 \%, 84.20 \%$, non- corroded by $27.08 \%, 55.90 \%$ and $47.14 \%$ respectively. For corroded cube concrete members, the values were lower by $21.30 \%$, $38.80 \%$ and $32.00 \%$ on failure load, bond strength and maximum slip to those ones obtained by non-corroded and coated members. The entire results showed good bonding characteristic and effectiveness in the use of ficus glumosa resins / exudates as protective materials against corrosion.

${ }^{[10]}$ investigated the primary causes of the reduction of service life, integrity and capacity of reinforced concrete structures in the marine environment of saline origin is corrosion. Results obtained on comparison showed failure bond load, bond strength and maximum slip decreased in corroded specimens to $21.30 \%, 38.80 \%$ and $32.00 \%$ respectively, while coated specimens $51.69 \%, 66.90 \%, 74.65 \%$, for non-corroded specimen, $27.08 \%, 55.90 \%$ and $47.14 \%$. Entire results showed lower percentages in corroded and higher in coated members. This justifies the effect of corrosion on the strength capacity of corroded and coated members.

${ }^{[11]}$ Charles et. al (2018) investigated the Corrosion of steel reinforcement in concrete is one of the principal factor that caused the splitting failures that occurred between steel and concrete, the used of epoxy, resin/exudates has been introduced to curb this trend encountered by reinforced structures built within the saline environment. Pullout bond strength test results of failure bond load, bond strength and maximum slip were $21.30 \%$, $36.80 \%$ and $32.00 \%$ for corroded members, $36.47 \%, 64.00 \%$ and $49.30 \%$ for coated members respectively. The values of corroded members were lower compared to coated members. Results showed that resins / exudates enhances strength to reinforcement and serves as protective coat against corrosion.

${ }^{[12]}$ Investigated the effectiveness of resin/exudates in corrosion prevention of reinforcement in reinforced concrete cubes. Results obtained indicated that the failure bond strength, pull out bond strength and maximum slip of the resin coated reinforced cubes were higher by $(19 \%),(84 \%)$ and $(112 \%)$. respectively than those obtained from the controlled tests. Similar results were obtained for the maximum slip (the resin coated and non-corroded steel members) had higher values of maximum slip compared to the cubes that had corroded steel reinforcements. For the corroded beam members, the failure bond strength, pull out bond strength and maximum slip of the resin coated reinforcements were lower by (22\%), (32\%) and $(32 \%)$. respectively than those obtained from the controlled tests.

[13] investigated the effect of corroded and inhibited reinforcement on the stress generated on pullout bond splitting of non-corroded, corroded and resins / exudates paste coated steel bar. In comparison, failure loads of Symphonia globulifera linn, Ficus glumosa, Acardium occidentale 1 are $36.47 \%, 32.50 \%$ and $29.59 \%$ against $21.30 \%$ corroded, bond strength are $64.00 \%, 62.40 \%, 66.90$ against $38.88 \%$ and maximum slip are $89.30 \%, 84.20 \%, 74.65 \%$ against $32.00 \%$ corroded. Entire results showed values increased in coated compared to 
corroded specimens resulted to adhesion properties from the resins / exudates also enhances strength to reinforcement and serves as protective coat against corrosion.

${ }^{[14]}$ Studied the bond strength exhibited by reinforcement embedded in concrete is controlled by corrosion effects. Pullout bond strength results of failure load, bond strength and maximum slip for dacryodes edulis are $75.25 \%, 85.30 \%, 97.80 \%$, moringa oleifera lam; $64.90 \%, 66.39 \%, 85.57 \%$, magnifera indica; $36.49 \%, 66.30 \%$ and $85.57 \%$, for non-corroded, $27.08 \%, 5590 \%$ and $47.14 \%$ while corroded are $21.30 \%, 36.80 \%$ and $32.00 \%$. The entire results showed lower values in corroded specimens as compared to coated specimens; coated members showed higher bonding characteristics variance from dacryodes edulis (highest), moringa oleifera lam (higher) and magnifera indica (high) and coated serves as resistance and protective membrane towards corrosion effects.

\subsection{EXPERIMENTAL PROGRAM}

The present study involves direct application of resins / exudates of trees extract known as inorganic inhibitor, coated on the reinforcing steel surface and were studied in this test program. The main objective of this study was to determine the effectiveness of locally available surface-applied corrosion inhibitors under severe corrosive environments and with chloride contamination. The test setup simulates a harsh marine environment of saline concentration in the concrete in the submerged portion of the test specimens, corrosion activity of the steel cannot be sustained in fully immersed samples. The samples were designed with sets of reinforced concrete cubes of $150 \mathrm{~mm} \times 150 \mathrm{~mm} \times 150 \mathrm{~mm}$ with a single ribbed bar of $12 \mathrm{~mm}$ diameter embedded in the centre of the concrete cube specimens for pull out test and was investigated. To simulate the ideal corrosive environment, concrete samples were immersed in solutions $(\mathrm{NaCl})$ and the depth of the solution was maintained.

\subsection{Aggregates}

The fine aggregate and coarse aggregate were purchased. Both met the requirements of ${ }^{[15]}$

\subsubsection{Cement}

Portland limestone cement grade 42.5 is the most and commonly type of cement in Nigerian Market. It was used for all concrete mixes in this investigation. The cement met the requirements of ${ }^{[16]}$

\subsubsection{Water}

The water samples were clean and free from impurities. The fresh water used was gotten from the tap at the Civil Engineering Department Laboratory, Kenule Beeson Polytechnic, Bori, and Rivers State. The water met the requirements of ${ }^{[17]}$

\subsubsection{Structural Steel Reinforcement}

The reinforcements are gotten directly from the market in Port Harcourt, met requirement to [18]

\subsubsection{Corrosion Inhibitors (Exudate/Resin) Invingia Gabonensis}

The study inhibitor (Invingia Gabonensis ) is of natural tree resin /exudate substance extracts. It was sourced from farm plantation, in Ahoada - West Local Government of Rivers State, Nigeria

\subsection{Experimental Procedures}

\subsubsection{Experimental method}

\subsubsection{Sample preparation for reinforcement with coated resin/exudate}

Corrosion tests were performed on high yield steel (reinforcement) of $12 \mathrm{~mm}$ diameter with $550 \mathrm{~mm}$ lengths for cubes, Specimen surfaces roughness was treated with sandpaper / wire brush and specimens were cleaned with distilled water, washed by acetone and dried properly, then polished and coated with ((Invingia Gabonensis exudate), resin pastes with 
coating thicknesses of $150 \mu \mathrm{m}, 300 \mu \mathrm{m}$ and $450 \mu \mathrm{m}$ before corrosion test. The test cubes and beams were cast in steel mould of size $150 \mathrm{~mm} \times 150 \mathrm{~mm} \times 150 \mathrm{~mm}$. The specimens were cured at room temperature in the curing tanks for accelerated corrosion test process and testing procedure allowed for 120 days first crack noticed and a further 30 days making a total of 150 days for further observations on corrosion acceleration process.

\subsubsection{Accelerated corrosion set-up and testing procedure}

In real and natural conditions the development of reinforcement corrosion is very slow and can take years to be achieved; as a result of this phenomenon, laboratory studies necessitate an acceleration of corrosion process to achieve a short test period. After curing the cubes specimens for 28 days, specimens were lifted and shifted to the corrosion tank to induce desired corrosion levels. Electrochemical corrosion technique was used to accelerate the corrosion of steel bars embedded in cubes specimens. Specimens were partially immersed in a $5 \% \mathrm{NaCl}$ solution for duration of 150 days, to examine the surface and mechanical properties of rebar.

\subsection{Pull-out Bond Strength Test}

The pull-out bond strength tests on the concrete cubes were performed 9 specimens each of non-corroded, corroded and exudates/resins coated specimens, totaling 27 specimens on Universal Testing Machine of capacity $50 \mathrm{KN}$ in accordance with BS EN 12390-2. The dimensions of the pull-out specimens were 27 cubes $150 \mathrm{~mm} \times 150 \mathrm{~mm} \times 150 \mathrm{~mm}$ with a single ribbed bar of $12 \mathrm{~mm}$ diameter embedded in the centre of the concrete cube. After 150 days, the accelerated corrosion subjected samples were examined to determine bond strength effects due to corrosion and corrosion inhibited samples. Specimens of $150 \mathrm{~mm}$ x150 mm $\mathrm{x} 150 \mathrm{~mm}$ concrete cube specimens were also prepared from the same concrete mix used for the cubes, cured in water for 28 days, and accelerated with $5 \% \mathrm{NaCl}$ solution for same 150 days making a total of 178 days was consequently tested to determine bond strength.

\subsection{Tensile Strength of Reinforcing Bars}

To ascertain the yield and tensile strength of tension bars, bar specimens of $12 \mathrm{~mm}$ diameter of Control, corroded and coated were tested in tension in a Universal Testing Machine and were subjected to direct tension until failure; the yield, maximum and failure loads being recorded. To ensure consistency, the remaining cut pieces from the standard length of corroded and Control steel bars were subsequently used in the bond and flexural test.

\subsection{EXPERIMENTAL RESULTS AND DISCUSSION}

Tables 3.1, 3.2 and 3.3 are the detailed results of pullout bond strength test of failure bond load, bond strength and maximum slip obtained from 27 samples of control, corroded and Invingia Gabonensis exudates/ resins steel bar coated specimens paste on reinforcement embedded in concrete cubes member. Table 3.4 and 3.5 showed the results of average and summary pull-out bond strength values of failure load, bond strength and maximum slip of control, corroded and resins/exudates coated specimens. Figures 3.1 and 3.2 are the plots of entire failure bond load versus bond strength and bond strength versus maximum slip, while figures 3.3 and 3.4 are the plots of average failure bond load versus maximum slip obtained from tables 3.1, 3.2 and 3.3

\subsection{Control Concrete Cube Members}

Specimens randomly sampled from table 3.1, were summarized into tables 3.4 and 3.5, also, shown in figures $3.1-3.4$ are graphically presentations. Failure bond load averaged values are $28.65 \mathrm{kN}, 29.52667 \mathrm{kN}$ and $29.22667 \mathrm{kN}$, and averaged to $29.13444 \mathrm{kN}$ and represented 
$77.48071 \%$ percentile value. Averaged bond strength values are $9.77 \mathrm{MPa}, 10.19 \mathrm{MPa}$ and $10.19 \mathrm{MPa}$, into $10.05 \mathrm{MPa}$ and percentile value of $81.26253 \%$. Averaged maximum slip values are $0.110167 \mathrm{~mm}, 0.119167 \mathrm{~mm}$, and $0.1165 \mathrm{~mm}$ summed to $0.115278 \mathrm{~mm}$ represented $42.02601 \%$ percentile values.

\subsection{Corroded Concrete Cube Members}

Specimens randomly sampled from table 3.1, into 3.4 and 3.5, as shown in figures $3.1-3.4$, averaged failure bond load are $16.41333 \mathrm{kN}, 16.44667 \mathrm{kN}$ and $16.38667 \mathrm{kN}$, summed to $16.41556 \mathrm{kN}$, represented $-43.6558 \%$ against $77.48071 \%$ and $77.10843 \%$ percentile difference of control and coated exudates/resin member. Averaged bond strength load $5.483333 \mathrm{MPa}, \quad 5.663333 \mathrm{MPa}, \quad 5.486667 \mathrm{MPa}$ summed to $5.544444 \mathrm{MPa}$, represented percentile value of $-44.8314 \%$ against $81.26253 \%$ and $116.4128 \%$ percentile difference of control and coated. Averaged maximum slip values are $0.0775 \mathrm{~mm}, 0.0775 \mathrm{~mm}$, $0.081167 \mathrm{~mm}$, summed to $0.081167 \mathrm{~mm}$, represented $-29.5904 \%$ against $42.02601 \%$ and $92.81314 \%$ percentile difference of control and coated. Relatively, corroded specimens showed lower failure load and bond strength properties to exudates coated and controlled specimens.

\subsection{Invingia Gabonensis Exudates/ Resins Steel Bar Coated Specimens Steel Bar Coated}

\section{Concrete Cube Members}

Specimens randomly sampled from table 3.1 to 3.3 and into 3.4 and 3.5, as shown in figures $3.1-3.4$, failure bond load averaged values are $28.16333 \mathrm{kN}, 29.47667 \mathrm{kN}, 29.58 \mathrm{kN}$ summed to $29.07333 \mathrm{kN}$, represented $77.10843 \%$ over $-43.6558 \%$ corroded percentile differences, averaged bond strength values are $11.62 \mathrm{MPa}, 11.76 \mathrm{MPa}, 12.61667 \mathrm{MPa}$ summed to $11.99889 \mathrm{MPa}$, represented $116.4128 \%$ over $-44.8314 \%$ and averaged maximum slip values are $0.1355 \mathrm{~mm}, 0.143833 \mathrm{~mm}, 0.190167 \mathrm{~mm}$ summed to $0.1565 \mathrm{~mm}$ represented $92.81314 \%$ over $-29.5904 \%$ corroded percentile differences. Exudates/resins coated specimens exhibited inhibitive characteristics to corrosion with recorded higher low failure load, high bond and maximum slip strength over corroded specimens

Table 3.1: Results of Pull-out Bond Strength Test ( $\tau u)$ (MPa)

\begin{tabular}{|c|c|c|c|c|c|c|c|c|c|c|}
\hline S/no & & \multicolumn{9}{|c|}{ Non-corroded Control Cube Specimens } \\
\hline $\begin{array}{l}\text { Concrete } \\
\text { Cube }\end{array}$ & Sample & ACA1 & BCA1 & CCA1 & DCA1 & ECA1 & FCA1 & GCA1 & HCA1 & ICA1 \\
\hline CCSA1-1 & $\begin{array}{l}\text { Failure } \\
\text { Bond } \\
\text { Loads } \\
(\mathrm{kN})\end{array}$ & 29.39 & 28.53 & 28.03 & 30.24 & 28.74 & 29.6 & 29.74 & 28.54 & 29.4 \\
\hline CCSA1-2 & $\begin{array}{l}\text { Bond } \\
\text { strength } \\
(\mathrm{MPa})\end{array}$ & 9.9 & 9.77 & 9.64 & 10.3 & 9.76 & 10.51 & 10.3 & 10.36 & 9.91 \\
\hline CCSA1-3 & $\begin{array}{l}\text { Max. slip } \\
(\mathrm{mm})\end{array}$ & 0.1235 & 0.1085 & 0.0985 & 0.1285 & 0.1115 & 0.1175 & 0.1185 & 0.1035 & 0.1275 \\
\hline CSA1-4 & $\begin{array}{l}\text { Bar } \\
\text { diameter } \\
(\mathrm{mm})\end{array}$ & 12 & 12 & 12 & 12 & 12 & 12 & 12 & 12 & 12 \\
\hline
\end{tabular}




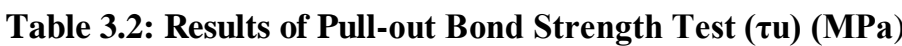

\begin{tabular}{|l|c|c|c|c|c|c|c|c|c|c|}
\hline S/no & \multicolumn{9}{|c|}{ Corroded Cube Specimens } \\
\hline $\begin{array}{l}\text { Concrete } \\
\text { Cube }\end{array}$ & Sample & ACA2 & BCA2 & CCA2 & DCA2 & ECA2 & FCA2 & GCA2 & HCA2 & ICA2 \\
\hline $\begin{array}{l}\text { CCSA 2- } \\
1\end{array}$ & $\begin{array}{c}\text { Failure } \\
\text { Bond load } \\
(\mathrm{KN})\end{array}$ & 15.99 & 16.74 & 16.51 & 16.97 & 16.22 & 16.15 & 16.74 & 16.22 & 16.2 \\
\hline $\begin{array}{l}\text { CCSA 2- } \\
2\end{array}$ & $\begin{array}{c}\text { Bond } \\
\text { strength } \\
(\mathrm{MPa})\end{array}$ & 5.1 & 5.75 & 5.6 & 6.12 & 5.56 & 5.31 & 5.72 & 5.41 & 5.33 \\
\hline $\begin{array}{l}\text { CCSA 2- } \\
3\end{array}$ & $\begin{array}{c}\text { Max. slip } \\
(\mathrm{mm})\end{array}$ & 0.0625 & 0.0885 & 0.0815 & 0.0935 & 0.0805 & 0.0805 & 0.0865 & 0.0785 & 0.0785 \\
\hline CCSA2-4 & $\begin{array}{c}\text { Bar } \\
\text { diameter } \\
(\mathrm{mm})\end{array}$ & 12 & 12 & 12 & 12 & 12 & 12 & 12 & 12 & 12 \\
\end{tabular}

Table 3.3: Results of Pull-out Bond Strength Test ( $\tau u$ ) (MPa)

\begin{tabular}{|c|c|c|c|c|c|c|c|c|c|c|}
\hline & & \multicolumn{9}{|c|}{ Invingia Gabonensis Exudate ( steel bar coated specimen) } \\
\hline S/No & & \multicolumn{3}{|c|}{$(150 \mu \mathrm{m})$ Coated } & \multicolumn{3}{|c|}{$(300 \mu m)$ Coated } & \multicolumn{3}{|c|}{$(450 \mu \mathrm{m})$ Coated } \\
\hline $\begin{array}{l}\text { Concrete } \\
\text { Cube }\end{array}$ & Sample & Aca3 & Bca3 & $\mathrm{Cca3}$ & Dca3 & Eca3 & Fca3 & Gca3 & Hca3 & Ica3 \\
\hline Ccsa3-1 & $\begin{array}{l}\text { Failure } \\
\text { Load }(\mathrm{Kn})\end{array}$ & 28.25 & 27.8 & 28.44 & 29.03 & 29.85 & 29.55 & 29.76 & 29.93 & 29.05 \\
\hline Ccsa3-2 & $\begin{array}{l}\text { Bond } \\
\text { Strength } \\
\text { (Mpa) }\end{array}$ & 11.99 & 12.19 & 10.68 & 11.19 & 11.99 & 12.1 & 13.09 & 12.39 & 12.37 \\
\hline Ccsa3-3 & $\begin{array}{l}\text { Max. Slip } \\
(\mathrm{Mm})\end{array}$ & 0.1455 & 0.1355 & 0.1255 & 0.1425 & 0.1355 & 0.1535 & 0.1815 & 0.1955 & 0.1935 \\
\hline CCSA3-4 & $\begin{array}{l}\text { Bar } \\
\text { diameter } \\
(\mathrm{mm})\end{array}$ & 12 & 12 & 12 & 12 & 12 & 12 & 12 & 12 & 12 \\
\hline
\end{tabular}

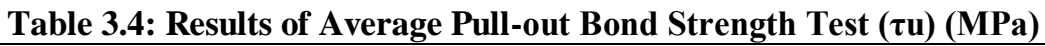

\begin{tabular}{|c|c|c|c|c|c|c|c|c|c|c|}
\hline & & \multicolumn{9}{|c|}{ Control, Corroded and Resin Steel bar Coated } \\
\hline S/no & & \multicolumn{3}{|c|}{ Non-corroded Control Cube } & \multicolumn{3}{|c|}{ Corroded Cube Specimens } & \multicolumn{3}{|c|}{$\begin{array}{c}\text { Exudate steel bar coated } \\
\text { specimens }\end{array}$} \\
\hline $\begin{array}{l}\text { Concrete } \\
\text { Cube }\end{array}$ & Sample & $\begin{array}{l}\text { Non-Corrc } \\
\text { Values }\end{array}$ & d Specimen & Average & $\begin{array}{l}\text { Corroded } \\
\text { Values }\end{array}$ & ecimens A & & $\begin{array}{l}\text { Coated Spe } \\
\text { of } 150 \mu \mathrm{m} \text {, }\end{array}$ & mens Aver & Values \\
\hline CCSA4-1 & $\begin{array}{l}\text { Failure } \\
\text { load } \\
(\mathrm{KN})\end{array}$ & 28.65 & 29.52667 & 29.22667 & 16.41333 & 16.44667 & 16.38667 & 28.16333 & 29.47667 & 29.58 \\
\hline CCSA4-2 & $\begin{array}{l}\text { Bond } \\
\text { strength } \\
\text { (MPa) }\end{array}$ & 9.77 & 10.19 & 10.19 & 5.483333 & 5.663333 & 5.486667 & 11.62 & 11.76 & 12.61667 \\
\hline CCSA4-3 & $\begin{array}{l}\text { Max. } \\
\text { slip } \\
(\mathrm{mm})\end{array}$ & 0.110167 & 0.119167 & 0.1165 & 0.0775 & 0.084833 & 0.081167 & 0.1355 & 0.143833 & 0.190167 \\
\hline CCSA4-4 & $\begin{array}{l}\text { Bar } \\
\text { diameter } \\
(\mathrm{mm})\end{array}$ & 12 & 12 & 12 & 12 & 12 & 12 & 12 & 12 & 12 \\
\hline
\end{tabular}


Table 3.5: Results of Average Pull-out Bond Strength Test ( $\tau u$ ) (MPa)

\begin{tabular}{|c|c|c|c|c|c|c|c|c|c|c|}
\hline & & \multicolumn{3}{|c|}{$\begin{array}{c}\text { Non-Corroded Specimens Average } \\
\text { Values }\end{array}$} & \multicolumn{3}{|c|}{ Percentile Values } & \multicolumn{3}{|c|}{ Percentile Difference } \\
\hline $\begin{array}{l}\text { CCSA5- } \\
1\end{array}$ & $\begin{array}{l}\text { Failure } \\
\text { load } \\
(\mathrm{KN})\end{array}$ & 29.13444 & 16.41556 & 29.07333 & 177.4807 & 56.34415 & 177.1084 & 77.48071 & -43.6558 & 77.10843 \\
\hline $\begin{array}{l}\text { CCSA5- } \\
2\end{array}$ & $\begin{array}{l}\begin{array}{l}\text { Bond } \\
\text { strength } \\
\text { (MPa) }\end{array} \\
\end{array}$ & 10.05 & 5.544444 & 11.99889 & 181.2625 & 55.1686 & 216.4128 & 81.26253 & -44.8314 & 116.4128 \\
\hline $\begin{array}{l}\text { CCSA5- } \\
3\end{array}$ & $\begin{array}{l}\text { Max. slip } \\
(\mathrm{mm})\end{array}$ & 0.115278 & 0.081167 & 0.1565 & 142.026 & 70.40964 & 192.8131 & 42.02601 & -29.5904 & 92.81314 \\
\hline $\begin{array}{l}\text { CCSA5- } \\
4\end{array}$ & $\begin{array}{l}\begin{array}{l}\text { Bar } \\
\text { diameter } \\
(\mathrm{mm})\end{array} \\
\end{array}$ & 12 & 12 & 12 & 100 & 100 & 100 & 0 & 0 & 0 \\
\hline
\end{tabular}

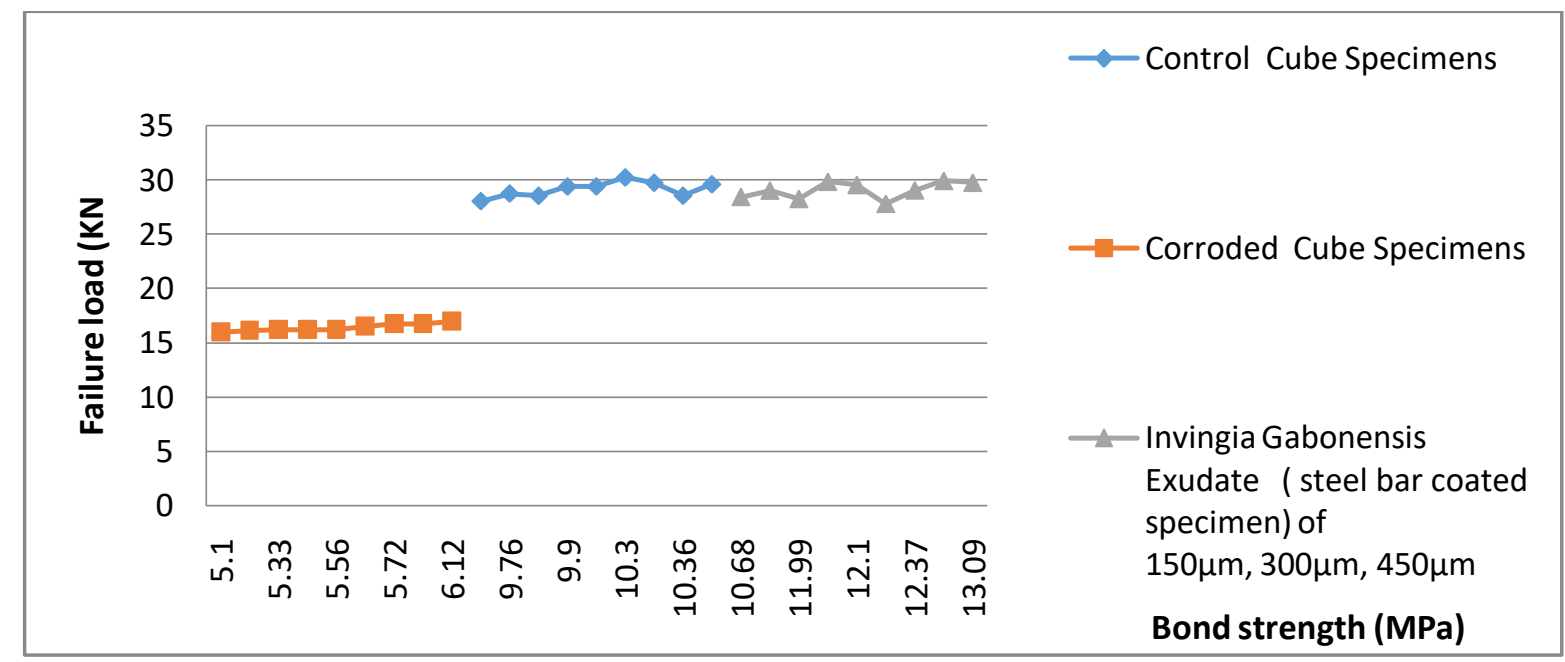

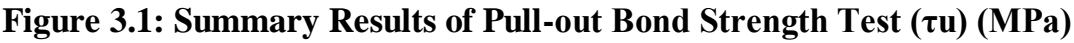
(Failure loads versus Bond Strengths

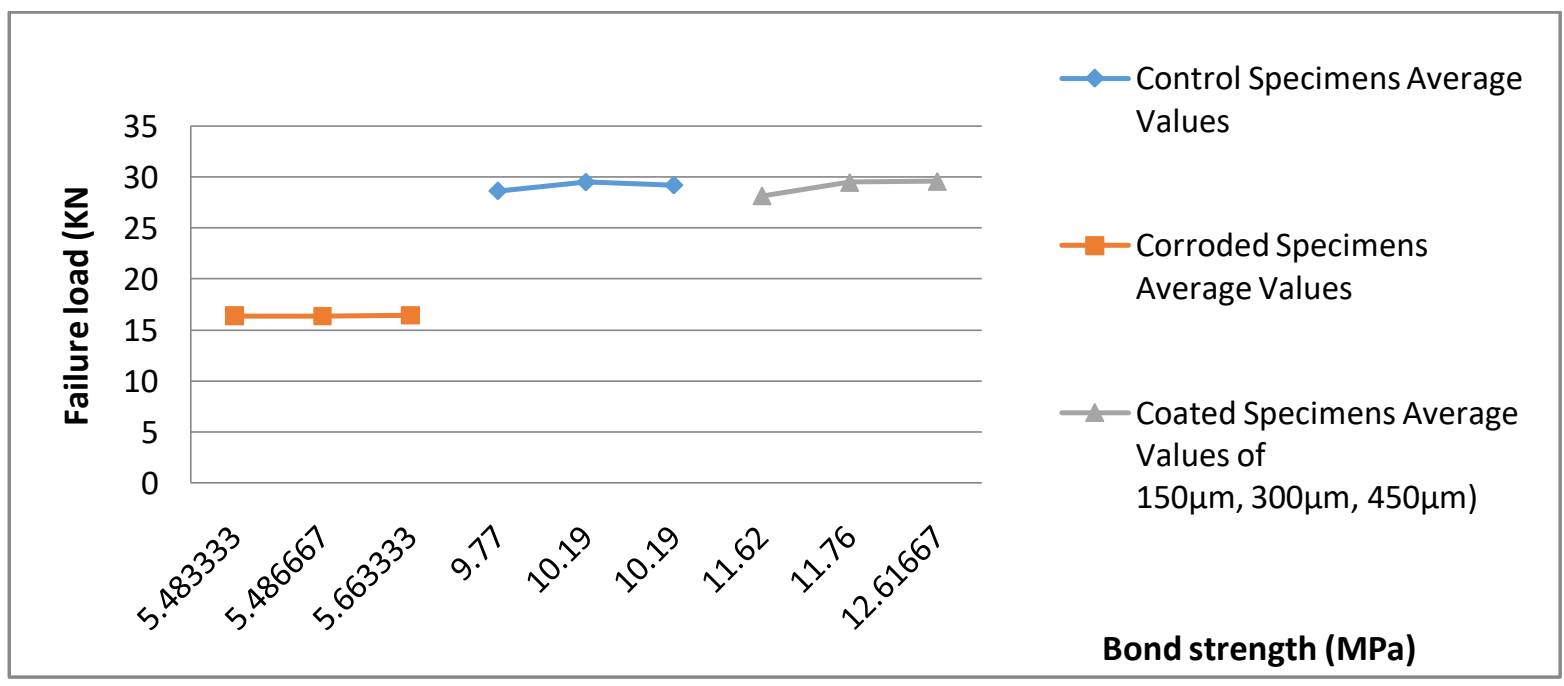

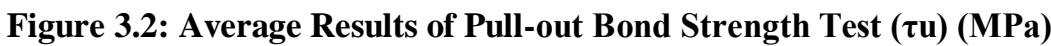
(Failure loads versus Bond Strengths) 


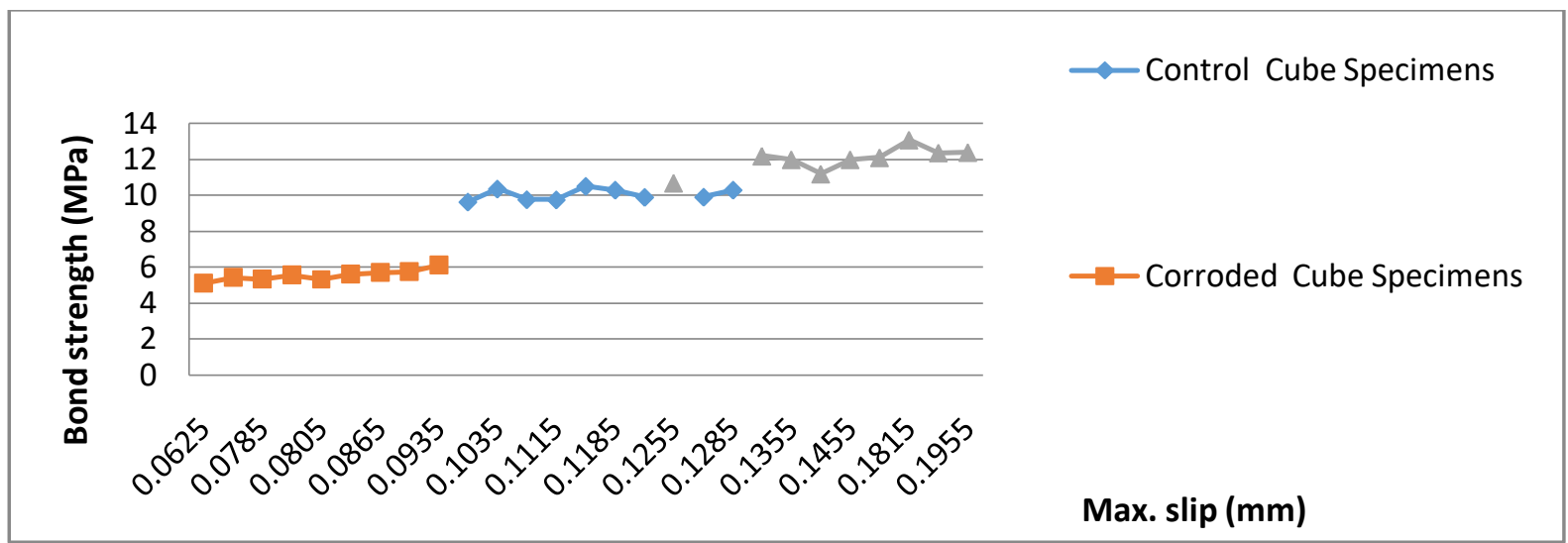

Figure 3.3: Summary Results of Pull-out Bond Strength Test ( $\tau u$ ) (MPa) (Bond Strength versus Maximum Slip)

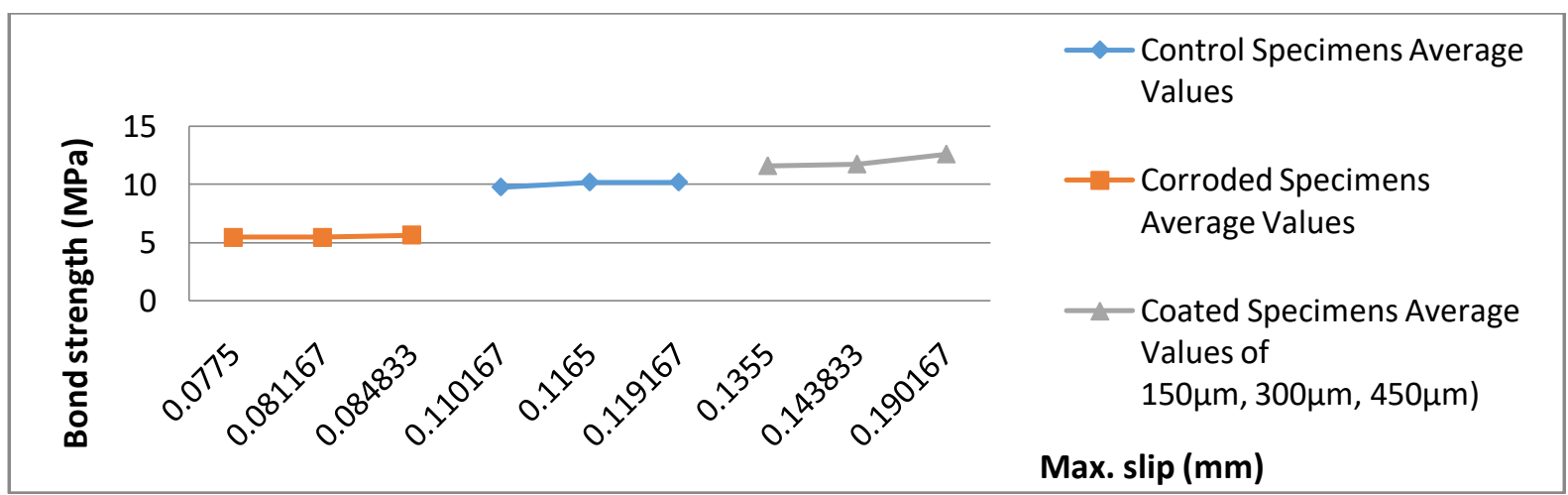

Figure 3.4: Average Results of Pull-out Bond Strength Test ( $\tau u)$ (MPa) (Bond Strength versus Maximum Slip)

\subsection{CONCLUSION}

Experimental results showed the following conclusions:

i. Exudates/resins coated specimens exhibited inhibitive characteristics to corrosion

ii. Exudate/resin coated steel specimens with recorded higher low failure load high bond and maximum slip strength over corroded specimens

iii. Low strength capacities of corroded specimens were recorded with higher failure bond load.

iv. Higher bond stresses were experienced in exudates /resin coated reinforcements over controlled specimens

v. Invingia Gabonensis exudates/ resins showed potential of corrosion inhibitive characteristic

\section{REFERENCES}

1. Al-Sulaimani, G. J. Kaleemullah, M. Basunbul, I. A. and Rasheeduzzafar, A. (1990).Influence of Corrosion and Cracking on Bond Behavior and Strength of Reinforced Concrete Members. ACI Structural Journal, 87: 220-231.

2. Mangat, P. and Elgarf, M. S. (1999). Flexural Strength of Concrete Beams with Corroding Reinforcement. ACI Structural Journal, 96:149-158.

3. Almusallam, A. Ahmed, S. Gahtani, A. and Rauf, A. (1995). Effect of Reinforcement

Corrosion on Bond Strength. Construction and Building Materials, 10:123-129. 
4. Cabrera, J. G. (1996). Deterioration of Concrete due to Reinforcement Steel Corrosion. Cement and Concrete Composites, 18(1):47-59.

5. Auyeung, Y. Balaguru, P. and Chung, L. (2001). Bond Behavior of Corroded Reinforcement Bars. ACI Materials Journal, 97(2): 214-220.

6. Amleh, L. and Mirza, M. S. (1999). Corrosion Influence on Bond between Steel and Concrete. ACI Structural Journal, 96: 415-423.

7. Fang, C. Lundgren, K. Chen, L. and Zhu, C. 2004. Corrosion Influence on Bond in Reinforced Concrete. Cement and Concrete Research, 34: 2159-2167.

8. Ouglova, A. Berthaud, Y. Foct, F. François, M. Ragueneau, F. and Petre-Lazar, I. (2008).The Influence of Corrosion on Bond Properties between Concrete and Reinforcement in Concrete Structures. Materials and Structures, 41: 969-980.

9. Charles, K. Latam, L. P. Ugo, K. (2018). Effect of Corrosion on Bond between Steel and Concrete of Corroded and Inhibitive Reinforcement Embedded in Reinforced Concrete Structures in Accelerated Corrosive Medium. International Journal of Scientific \& Engineering Research,(9)4:803-813.

10. Charles, K. Okabi, I. S. Terence, T. T.W. and Kelechi, O. (2018). Comparative Investigation of Pull-Out Bond Strength Variance of Resins \ Exudates Inhibitive and Corroded Reinforcement Embedded in Reinforced Concrete Structures, Exposed to Severely Environment. International Journal of Scientific \& Engineering Research, (9)4:641-654.

11. Charles, K. Gbinu, S. K. and Achieme, L. O. (2018). Effect of Corrosive Environment on Reinforced Concrete Structures Pullout Bond Strength of Corroded and Resins / Exudates Coated Reinforcement. International Journal of Scientific \& Engineering Research, (9) 4:814 - 824.

12. Otunyo, A.W and Kennedy, C. (2018). Effectiveness of Resins/Exudates of Trees in Corrosion Prevention of Reinforcement in Reinforced Concrete structures, Nigerian Journal of Technology, 37:78-86.

13. Charles, K. Akatah, B, M. Ishmael, O. and Akpan, P, P. (2018). Pullout Bond Splitting Effects of Reinforced Concrete Structures with Corroded and Inhibited Reinforcement in Corrosive Environment of Sodium Chloride. International Journal of Scientific \& Engineering Research,(9)4: 1123 - 1134.

14. Charles K, Gbinu S. K. Ogunjiofor, E. Okabi, I. S. (2018). Chloride Inducement on Bond Strength Yield Capacity of Uncoated and Resins / Exudates Inhibited Reinforcement Embedded in Reinforced Concrete Structures. International Journal of Scientific \& Engineering Research, (9)4:874 -885.

15. BS. 882; 1992- Specification for Aggregates from Natural Sources for Concrete. British Standards Institute. London, United Kingdom.

16. BS EN 196-6; 2010- Methods of Testing Cement. Determination of fineness, British Standards Institute. London, United Kingdom, 2010.

17. BS 3148; 1980 - Methods of test for Water for Making Concrete. British Standards Institute. London, United Kingdom.

18. BS 4449:2005+A3; 2010 - Steel for Reinforcement of Concrete. British Standards Institute. London, United Kingdom. 